\title{
A Preliminary Survey of Beach Forest Species in Guiuan Eastern Samar, Philippines: An Ethnobotanical Study
}

\author{
Joarth B. Sabulao', Joyce M. Magtolis ${ }^{1,2}{ }^{1}$, Catalina A. Capanang ${ }^{1}$, \\ Daisy E. Ingente ${ }^{1}$, Mark Wendolf E. Paa', Ronaldo C. Hitosis Jr.', \\ John Alvin Mabag' and Cyra C. Raga' \\ ${ }^{1}$ Graduate School, Leyte Normal University, Tacloban City, Philippines \\ ${ }^{2}$ College of Arts and Sciences, Leyte Normal University, Tacloban City, Philippines
}

\begin{abstract}
Article Type: Article
Article Citation: Joarth B. Sabulao, Joyce M. Magtolis, Catalina A.

Capanang, Daisy E. Ingente, Mark WendolfE. Paa, Ronaldo C. Hitosis Jr., John Alvin Mabag, Cyra C. Raga. A Preliminary survey of beach forest species in Guiuan Eastern Samar, Philippines: an ethnobotanical study. Indian Journal of Science and Technology. 2020; 13(09), 1098-1106. D0l: 10.17485/ijst/2020/ v013i09/149706
\end{abstract}

Received date: December 17, 2019

Accepted date: January 26, 2020

*Author for correspondence: Joyce M. Magtolis $\mathbf{D}$ jbm.magtolis@ gmail.com $\boldsymbol{\rho}$ Graduate School, Leyte Normal University, Tacloban City, Philippines

\begin{abstract}
Objectives/methods: A preliminary ethnobotanical survey of beach forest species was conducted to identify the local names and document the uses of these resources to the locals of Guiuan, Eastern Samar, Philippines. Plants were identified in situ by an informant and samples were collected for herbarium specimen identification. Ethnobotanical data were obtained using a modified focused group (bench conference) and a semi-structured interview with each of the 15 informants, composed of a village leader, a local healer, and mostly elders. Quantitative data on the citation of beach plants per specific use were tabulated for frequency counts and percentage of informant's citation or agreement. Findings/application: The study documented at least 39 species of beach forests flora present in the community. The common uses of these species by the locals are associated with construction, source of income, food and food processing for humans and domesticated animals, fishing technology, insect repellent, home decors, and furniture, landscaping, and folk medicine. Cocos nucifera $\mathrm{L}$. is evident in many applications in the life of the locals. Together with Atipulo (Artocarpus blancoi), and Bagnaw (Premna odorata), they were reported in diverse applications ranging from folk medicine to infrastructure and food preparation and consumption. Like any other ethnic group and underdeveloped communities in the world, medicinal administration is largely a symptomatic approach utilizing either fresh or dried leaves, fruits, roots, barks or even the whole plant across different preparations. The flexibility of some of these species in terms of utilization by the community can shed light on its abundance in the area and the associated local ecological knowledge. An ethnobotanical survey should be conducted across the Philippine archipelago for more comprehensive documentation of beach forest species, thereby giving cues on its dynamics and conservation efforts.
\end{abstract}

Keywords: Ethnobotany, Beach Forest Species, Descriptive Survey, Eastern Samar Ph. 


\section{Introduction}

Beach forest is among the green fronts along the extensive $36,300 \mathrm{~km}$ long coastline of the Philippine archipelago [1]. It features a plant community growing along the sand dunes and rocks on sandy shores towards the high tidal zones, exposed to salt spray [2], strong wind, and drought [3]. This supratidal vegetation dominated by littoral creepers, shrubs, and trees provides a greenbelt that reduces the effect of strong winds, coastal erosion, and wave actions [4]. It fulfills vast ecological functions that generate natural resources and ecosystem services that sustain the local and the national economies as well. Accordingly, this becomes one strategic location for settlement since the olden days where most of the early civilizations begun. Recently, coastal areas are home to one-third of the world's human population with densities nearly three times that of the inland areas, increasing exponentially [5]. Considering the many uses of coastal vegetation, from traditional to industrial applications, people living primarily by fishing, do not need shifting places in search of food [6] and other requisites to fishing, cultural utility, and the rest for living [7]. Consequently, the long-term human population sustainability along these areas resulted in centuries of wanton exploitation leading to an alarming degradation that dooms to vanish.

Furthermore, the vulnerability of the Philippines to natural disasters such as earthquakes and tsunamis being along the Pacific Ring of Fire, and typhoons and storm surges being a tropical cyclone gateway from the Pacific Ocean, puts more pressure to the weakening defensive stance offered by the mangrove forest as the coasts the first line of defense. Mangrove cover in some towns in the province of Eastern Samar, Philippines has been in the decline since 1987-2016, which are accounted for the human activities in the area while aggravated by more frequent tropical cyclones [8]. The town of Balankayan alone had experienced a massive mangrove forest damage to 86 percent tree density and 68 percent basal area, brought about by the 2013 Supertyphoon Haiyan [9]. Furthermore [10] as cited by [9] considered a negligible storm surge strength reduction rate due to its narrow vegetation cover. This vulnerability and its substrate selectivity make matters worse in conferring protection to coastal communities, pressing the need for reinforcement of Beach Forest. This landward vegetation cover is not only efficient greenbelt, but its species are also naturally tolerant of sea spray, strong sunlight and dry conditions, making them ideal reforestation species for climate change adaptation [4].

However, unlike the extensively studied and funded coastal counterparts in mangroves [11], a little study is known to beach forests resulting in unfamiliarity to average Filipino ensuing dismal conservation efforts thereby losing unreported in the Philippine Forestry Statistics [4]. Worthy of note is the fact that along with this forest degradation and modernization of indigenous communities is the loss of a large undocumented repository of traditional knowledge and experiences donned by the local folks [12]. Therefore, understanding forest dynamics and local dependency provides a holistic view emphasizing the role of ethnoscientific approaches by integrating indigenous knowledge into contemporary frameworks for conservation and sustainable management of natural resources [13]. 
It is on this note that this study entitled, "A Preliminary Survey of Beach Forest Species in Guiuan Eastern Samar, Philippines: An Ethnobotanical Study," was conceived. It aimed to a.) identify the local names of beach plant species, and to b.) document the uses of the beach forest species to the local folks in the study area.

\section{Methodology}

\subsection{Study Site}

The conduct of the study was at Sitio Comverse, Brgy. Ngolos, Guiuan, Eastern Samar (Figure 1), a coastal community bounded by the Pacific Ocean on the East, and the Leyte Gulf to the west (110 02'N $\left.125044^{\prime} \mathrm{E}\right)$. A feeder road of 1 and a half kilometers along a mountainous terrain connects the secluded community to the provincial highway. Smooth pavements made the area accessible by any land vehicle or through a motorized and nonmotorized boat if coursing through the sea. The land area is about 105 hectares, with an elevation estimated at 21.8 meters or 71.5 feet above mean sea level. It has 75 households $(\mathrm{HH})$ with $60 \mathrm{HH}$ into fishing while the rest are into farming and varied activities. Being laid along the eastern seaboard attributes to its rolling to flat topography. The article on

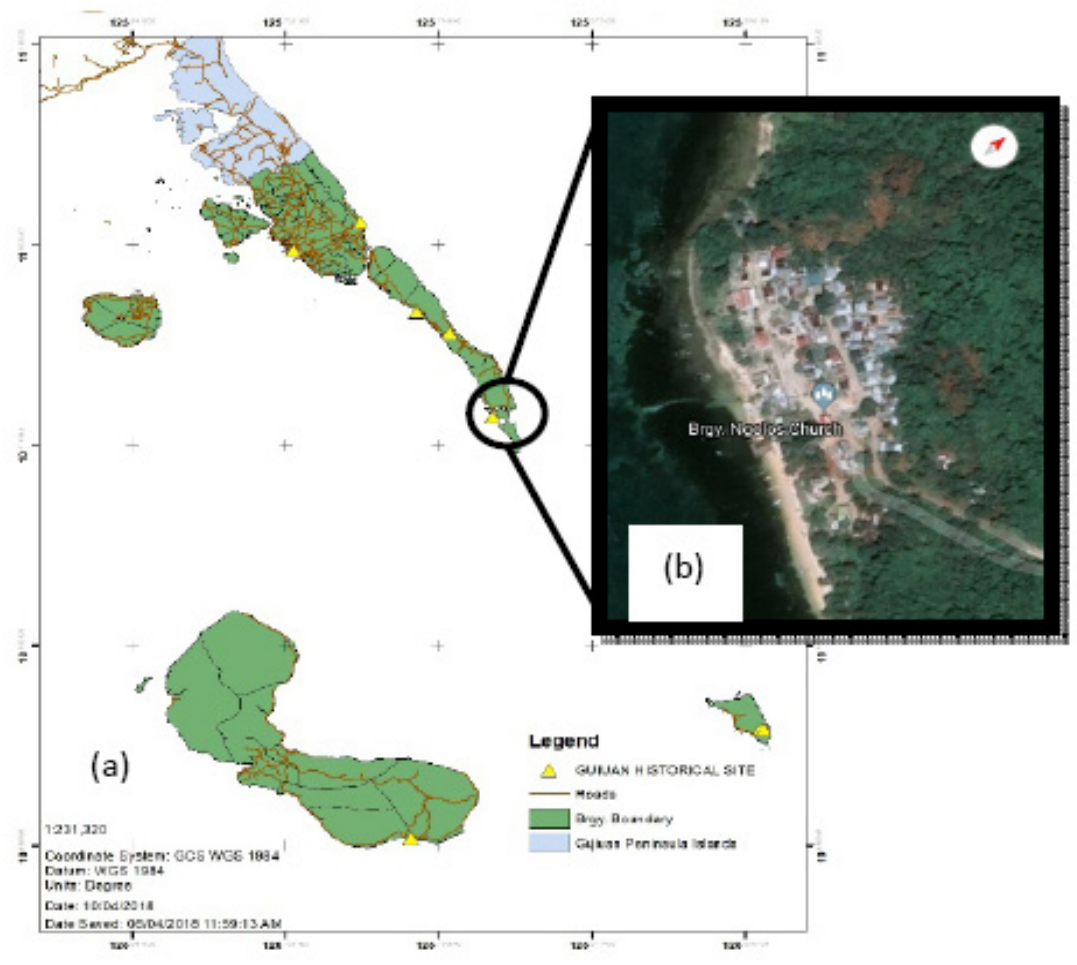

FIGURE 1. Study site: Maps of the Municipality of Guiuan (a) (source: Guiuan-CLUP, 2002015) showing Sitio Comverse, Brgy. Ngolos, Guiuan, Eastern Samar (b) (source: Google Earth, 2019). 
drought conditions and management strategies in the Philippines reported the area as having a climate Type II characterized by the absence of a dry season, but with a very pronounced maximum rain period from December to February [14] and an average annual rainfall of $3146.6 \mathrm{~mm}$ [15]. The area is rich with beach forest species and mangrove associates, which people utilize for different purposes. There is, however, the need to address conservation measures to ensure the continuity of the different species thriving in the coastal ecosystem more so is the fact that the site is part of the declared protected landscape/seascape in 1994 under the National Integrated Protected Areas System Act of 1992.

\subsection{Plant Identification and Collection}

The field study and interview was conducted during the months of November and December 2018 and in March 2019. Three (3) sets of $10 \times 10$ meters quadrat were randomly placed along the beach up to the high rocky segments of the coast to document the present species. Collected plants were identified in the field by one informant/guide who identified the local names, while morphology and habits were compared and verified through the book Beach Forest Species and Mangrove Associates in the Philippines [4]. Herbaria specimens with photographs of their habits were taken in situ for proper identification and deposited in the Leyte Normal University Herbarium.

\subsection{Ethnobotanical Data Collection}

An informed consent was given to the Local Government Unit and the informants before the start of the study. Data were collected from a series of site visits and interviews. A modified focused group called "bench conference" was held during the initial visit for brainstorming, while a guided tour with one of the highly familiar folks on the forest was made during the field survey for plant identification and collection. Furthermore, a series of semi-structured interviews on local name identification and uses were conducted with each of the informants. A total of fifteen (15) informants participated through referrals and volunteerism, ranging from 55 to 85 years of age coincidental to Voeks's [16] notion that people acquire more knowledge with age. Selection of informants by gender was considered since some publications inferred that women tend to have a broader understanding in terms of medicinal plants than men [17] as attributed to their role in family health care in general, hence the pool of informants were composed mostly of females with nine (9). However, on a personal note, men tend to be more familiar with forest resources in terms of construction materials and wood collection for general use; hence six (6) male locals came out as referred by some participants. Furthermore, this pool of informants was composed of their lone local traditional healer, six fishers, and the rest being housewives.

\subsection{Data Analysis}

Results of the semi-structured interview, particularly on individual degree of familiarity and citation of beach plants per specific use, were tabulated for frequency counts and percentage of informant's citation or agreement. 


\section{Results and Discussion}

There were a total of thirty-nine (Table 1) beach forest species with ethnobotanical significance to the locals of Sitio Comverse, Brgy. Ngolos, Guiuan, Eastern Samar. Of the fifty-five identified beach forest species [4] found throughout the municipality of Guiuan, only 28 species were found in the area, while the rest of the 39 species are yet to be verified in different reputable herbaria. It implies a more intensive study on identification, species diversity and distribution in the area and the rest of the municipality.

TABLE 1. Summary of beach forest species, uses and informants' use citation.

\begin{tabular}{|c|c|c|c|c|}
\hline \multirow[t]{2}{*}{ Uses } & \multicolumn{2}{|c|}{ Plant name } & \multicolumn{2}{|c|}{ Informants' citation } \\
\hline & Local name & Scientific name & Frequency & Percentage \\
\hline \multicolumn{5}{|c|}{ 1. Diseases/medical emergencies } \\
\hline $\begin{array}{l}\text { Antiseptic/ } \\
\text { antibacterial }\end{array}$ & Maruk-barok & Millettia pinnata & 6 & 40 \\
\hline Bleeding & Sibukaw & & 4 & 26.67 \\
\hline Bone fractures/sprain & Dalakit itom & & 5 & 33.33 \\
\hline Cancer/cyst & Turay & & 3 & 20 \\
\hline Hair/scalp & Lubi & Cocos nucifera & 14 & 93.33 \\
\hline \multirow{4}{*}{ Jellyfish sting } & Dalunutan & & 10 & 66.67 \\
\hline & Lambayong & Ipomea pes-caprae & 9 & 60 \\
\hline & Malubago & Talipariti tiliaceum & 9 & 60 \\
\hline & Nino & Morinda citrifolia & 4 & 26.67 \\
\hline \multirow[t]{2}{*}{ Post-partum } & Malipagi & & 7 & 46.67 \\
\hline & Sibukaw & & 5 & 33.33 \\
\hline \multirow[t]{4}{*}{ Skin diseases } & Bagnaw & Premna odorata & 8 & 53.33 \\
\hline & Dalunutan & & 14 & 93.33 \\
\hline & Maruk-baruk & M. pinnata & 13 & 86.67 \\
\hline & Sunting & Cassia alata & 2 & 13.33 \\
\hline \multicolumn{5}{|l|}{ 2. Infrastructure } \\
\hline \multirow[t]{14}{*}{ Construction (house) } & Anahaw & $\begin{array}{l}\text { Saribous } \\
\text { rotundifolius }\end{array}$ & 9 & \\
\hline & An-an & Alstonia macrophylla & 2 & 13.33 \\
\hline & Atipulo & Artocarpus blancoi & 15 & 100 \\
\hline & Bagutwan & & 4 & 26.67 \\
\hline & Banahaw & & 1 & 6.67 \\
\hline & Banilad & Stericulla futida & 7 & 46.67 \\
\hline & Banuyo & $\begin{array}{l}\text { Wallaceodendron } \\
\text { celebicum }\end{array}$ & 14 & 93.33 \\
\hline & Bitu-on & Barringtonia asiatica & 7 & 46.67 \\
\hline & Dalakit itom & & 2 & 13.33 \\
\hline & Hamurawon & & 2 & 13.33 \\
\hline & Kisiw & & 8 & 53.33 \\
\hline & Lubi & C. nucifera & 15 & 100 \\
\hline & Talisay & Terminalia catappa & 6 & 40 \\
\hline & Utob-utob & Allophylus cobbe & 2 & 13.33 \\
\hline \multirow{3}{*}{ Boat making } & Atipulo & A. blancoi & 5 & 33.33 \\
\hline & Banagu & Thespesia populnea & 13 & 86.67 \\
\hline & Malubago & T. tiliaceum & 13 & 86.67 \\
\hline
\end{tabular}




\begin{tabular}{|c|c|c|c|c|}
\hline \multirow{8}{*}{$\begin{array}{l}\text { Wood fence/fish } \\
\text { corals }\end{array}$} & Dapdap & Erythrina variegata & 10 & 66.67 \\
\hline & Kisiw & & 14 & 93.33 \\
\hline & Lanete & $\begin{array}{l}\text { Wrightia pubescens } \\
\text { R. Br. }\end{array}$ & 1 & 6.67 \\
\hline & Nigad & $\begin{array}{l}\text { Glochidion littorale } \\
\text { Blume }\end{array}$ & 3 & 20 \\
\hline & Paitan & & 2 & 13.33 \\
\hline & Palalaso & & 3 & 20 \\
\hline & Salimbabangun & & 5 & 33.33 \\
\hline & Utob-utob & A. cobbe & 4 & 26.67 \\
\hline \multirow{3}{*}{$\begin{array}{l}\text { Home decors/ } \\
\text { landscaping furniture }\end{array}$} & Bantolinao & Maba buxifolia & 15 & 100 \\
\hline & Harun & Crinum asiaticum & 6 & 40 \\
\hline & Nito & $\begin{array}{l}\text { Lygodium } \\
\text { circinnatum }\end{array}$ & 13 & 86.67 \\
\hline \multicolumn{5}{|c|}{ 3. Food source \& processing } \\
\hline \multirow[t]{4}{*}{ Human food } & Bagubatwan & & 15 & 100 \\
\hline & Banilad tawo & Stericulla ceramica & 2 & 13.33 \\
\hline & Lubi & C. nucifera & 15 & 100 \\
\hline & Rimas & Artocarpos camansi & 15 & 100 \\
\hline \multirow[t]{4}{*}{ Animal feeds } & An-an & A. macrophylla & 2 & 13.33 \\
\hline & Banilad amo & Stericulla futida & 8 & 53.33 \\
\hline & Bitu-on & B. asiatica & 1 & 6.67 \\
\hline & Dalunutan & & 14 & 93.33 \\
\hline Ripening agent & Bagnaw & P. odorata & 13 & 86.67 \\
\hline Food wrapping & Anahaw & S. rotundifolius & 4 & 26.67 \\
\hline \multirow[t]{4}{*}{ Firewood } & Atipulo & A. blancoi & 8 & 53.33 \\
\hline & Bituon & B. asiatica & 12 & 80 \\
\hline & Lipata & Cerbera odollam & 11 & 73.33 \\
\hline & Sunting & C. alata & 6 & 40 \\
\hline \multicolumn{5}{|l|}{ 4. Other uses } \\
\hline \multirow[t]{3}{*}{ Fish poison } & Lagtang & Anamirta cocculus & 14 & 93.33 \\
\hline & Panabulon & Cerbera manghas & 6 & 40 \\
\hline & Tubli & & 1 & 6.67 \\
\hline Insect repellent & Bagnaw & P. odorata & 11 & 73.33 \\
\hline Musical instrument & Lanete & W. pubescens R. Br. & 2 & 13.33 \\
\hline
\end{tabular}

The results of the interviews revealed that the identified plants are used in various ways of life by the locals as classified into different categories of applications such as treatment of diseases/medical emergencies, infrastructure, food and food processing, and other uses. There were 15 plants identified that are used in 7 different medicinal applications. Specifically, most of the informants mentioned both (93.33\%) Lubi (C. nucifera), and Dalunutan as antiseptic/antibacterial and as a treatment for skin diseases, respectively. Like the Yaegl Aboriginal community [18], medicinal administration is mostly asymptomatic approach utilizing either fresh or dried leaves, fruits, roots, barks or even the whole plant across different preparations. The decoction is the most common preparation method employed, followed by a poultice. The locals have shared practices with some ethnobotany across the world in treating diseases or emergencies like using Ipomea pes-caprae (L.) R. $\mathrm{Br}$. [2] with confirmed proteolytic and hemolytic neutralizing activity against jellyfish sting [19-20] albeit a different version of poultice preparation by chewing the leaves and applying to the affected area which is convenient given the urgency of the situation. Interestingly, 
an anti-cancer reported in a plant named Turay which, according to the testimony of one informant from personal experience and word of mouth, has cured a family member cancer patient. Turay and the many species have associated pharmacological potentials stored in the local repository of knowledge while unknown, especially in the mainstream communities.

With a large beach forest cover surrounding the community, the locals have easy access to supplement their basic needs. In infrastructure, there were 25 species cited to be used in various construction purposes, from housing and fixtures and furniture to perimeter fencing and landscaping down to boat making and fish corrals (bunu-an). Explicitly, all informants agreed to use Lubi (C. nucifera) and Atipulo (A. blancoi) in building construction and fixtures with Banuyo (W. celebicum) being an excellent option (93.33\%). Likewise, all participants agreed to use Bantolinao (M. buxifolia) for home decoration and landscaping purposes. An alternative to commercially available food crops and ingredients were 13 identified species used for human and animal consumption as well as food preparation such as fruit ripening, wrapping, and firewood. Again, Lubi together with Rimas (A. camansi) and Bagubatwan were used by all informants as food or ingredients in food preparations for human consumption, while most of them (93.33\%) cited Dalunutan as an alternative feed to their livestock. As a fishing community, most of the informants mentioned the use of Lagtang (A. cocculus) in fish poisoning to improve the fish catch.

C. nucifera L., being coined as a "tree of life," is evident in many applications in the life of the locals. Together with Atipulo, Bagnaw, and Dalunutan, these were reported in diverse applications ( 3 uses) ranging from treatment of diseases or medical emergencies to infrastructure and food or food preparations. The flexibility of some of these species in terms of utilization by the community can shed light on its abundance in the area and the associated local ecological knowledge. In subsequent publications cited by [21], they unanimously correlated species availability to selectivity in wood and non-wood forest product cutting and collection which thereby giving cues on its dynamics and conservation measures.

\section{Conclusion}

This study provided information on different local names and the ethnobotanical significance of beach forest species found in an isolated community in Guiuan, E. Samar, Philippines. Apparently, out of fifty-five identified species, there were thirty-nine species found to have associated significance to the locals in the area. This significance based on the utilization of these resources in the way of life, such as conventional medicine, infrastructure, food and food preparation, and the many other applications in their economic and social activities. The increasing influence of the mainstream communities and the threats to this resource degradation can lead to the disappearance of this valuable repository of knowledge, undocumented. Thus, preservation and integration of local indigenous knowledge is not only a culturally-sensitive but also a direct approach to sustainable conservation efforts. 


\subsection{Recommendation}

It can be noted that some beach forest species were not identified based on scientific names and verified, hence further taxonomic studies and distribution are hereby needed. Studies on the bioactivity and phytochemical constituents are also recommended to give a scientific basis to their applications which will also give proper guidance to the locality regarding their practices.

\section{Acknowledgement}

The authors would like to extend invaluable appreciation to Mr. Maximo Cabanatan and the informants from Sitio Comverse, Brgy. Ngolos, Guiuan, Eastern Samar, whose wisdom on beach forest utilization, time and effort during a field interview and community organizing have been instrumental in the completion of this study.

\section{References}

1. Primavera JH, Esteban JMA. A review of mangrove rehabilitation in the Philippines: successes, failures, and future prospects. Wetlands Ecology Management 2008, 16, 345-358. DOI: 10.1007/ s11273-008-9101-y.

2. Neamsuvan O, Sengnon N, Seemaphrik N, Chouychoo M, Rungrat R, Bunrasri S. A survey of medicinal plants around upper Songkhla lake, Thailand. African Journal of Traditional Complementary Alternative Medicine. 2012, 12(2), 133-143. DOI: 10.5897/JMPR11.1395.

3. Rueangphanich N. Forest and forestry in Thailand. Academic Promoting Center: Bangkok, 2005; 40-42.

4. Primavera JH, Sadaba RS. Beach forest species and mangrove associates in the Philippines. SEAFDEC Aquaculture Department: Tigbauan, Iloilo. 2012; 154. https://www.worldcat.org/ title/beach-forest-species-and-mangrove-associates-in-the-philippines/oclc/972847862

5. Barbier EB, Koch EW, Silliman BR, Hacker SD, Wolanski E, Primavera JH, Granek EF, Polasky S, Aswani S, Cramer LA, Stoms DM, Kennedy CJ, Bael D, Kappel CV, Perillo GME, Reed DJ. Coastal ecosystem-based management with nonlinear ecological functions and values. Science. 2008, 319-321. DOI: 10.1126/science.1150349.

6. Anderson E. Plants and Man. University of California Press: Berkeley. 1967.

7. Thaman RR. Batiri kei baravi: the ethnobotany of pacific island coastal plants. Atoll Research Bulletin. 1992, 361. https://doi.org/10.5479/si.00775630.361.1

8. Buitre MJC, Zhang $\mathrm{H}$, Lin $\mathrm{H}$. The Mangrove forests change and impacts from tropical cyclones in the Philippines using time series satellite imagery. Remote Sensing. 2019, 11, 688. DOI: $10.3390 / \mathrm{rs} 11060688$.

9. Alura DP, Alura NC, Alura RPC. Mangrove forest and seagrass bed of Eastern Samar, Philippines: extent of damage by typhoon Yolanda. International Journal of Novel Research in Life Sciences. 2015, 2, 30-35. https://www.researchgate.net/publication/303737563_Mangrove_Forest_and_ Seagrass_Bed_of_Eastern_Samar_Philippines_Extent_of_Damage_by_Typhoon_Yolanda

10. Storm surge reduction by mangroves. http://www.naturalcoastalprotection.org/documents/ storm-surge-reduction-by-mangroves. Date accessed: 2012.

11. Lacerda LD, editor. Mangrove ecosystems: function and management. Springer: New York. 2002. 
12. World Commission on Environment and Development. Our common future. In: Population and Human Resources. 1987. http://www.un-documents.ned/wced-ocf.htm. Date accessed 06/01/2009.

13. Rist S, Dahdouh-Guebas F. Ethnosciences-a step towards the integration of scientific and traditional forms of knowledge in the management of natural resources for the future. Environment, Development and Sustainability. 2006, 8: 467-493. https://link.springer.com/ article/10.1007/s10668-006-9050-7

14. UN-Water country briefs Philippines. https://www.unwater.org. Date accessed: 18/12/2018.

15. Department of Agriculture-[RFU8] Eastern Visayas. https://www.darfu8.tripod.com. Date accessed: 29/11/2018.

16. Voeks RA. Are women reservoirs of traditional plant knowledge, gender, ethnobotany and globalization in northeast Brazil. Singapore Journal of Tropical Geography. 2007, 28(1), 7-20. https://doi.org/10.1111/j.1467-9493.2006.00273.x

17. Merétika AHC, Peroni N, Hanazaki N. Local knowledge of medicinal plants in three artisanal fishing communities (Itapoá, Southern Brazil), according to gender, age, and urbanization. Acta Botanica Brasilia. 2010, 24(2), 386-394.

18. Packer J, Brouwer N, Harrington D, Gaikwad J, Heron R, Yaegl Community Elders, Ranganathan S, Vemulpad S, Jamie J. An ethnobotanical study of medicinal plants used by the Yaegl community in northern New South Wales, Australia. Journal of Ethnopharmacology. 2012, 139(1), 244-255. DOI: 10.1016/j.jep.2011.11.008.

19. Pongprayoon U, Bohlin L, Wasuwat S. Neutralization of toxic effects of different crude jellyfish venoms by an extract of Ipomoea pes-caprae (L.) R. Br. Journal of Ethnopharmacology. 1991, 35(1), 65-69. https://doi.org/10.1016/0378-8741(91)90133-X

20. Sampson JH, Phillipson JD, Bowery NG, O’Neill MJ, Houston JG, Lewis JA. Ethnomedicinally selected plants as sources of potential analgesic compounds: indication of in vitro biological activity in receptor binding assays. Phytotherapy Research. 2000, 14(1), 24-29. https://doi. org/10.1002/(sici)1099-1573(200002)14:1\%3C24::aid-ptr537\%3E3.0.co;2-9

21. Walters BB. Patterns of local wood use and cutting of Philippine mangrove forests. Economic Botany.2005,59(1),66-76.https://www.mta.ca/uploadedFiles/Community/Bios/Brad_Walters/ Patterns\%20of\%20cutting\%20of\%20mangroves.pdf 